\title{
Food production and Earth's limits to growth in the Anthropocene
}

\author{
Review by Bruno Borsari* \\ Winona State University
}

Review of Breaking Boundaries: The Science of Our Planet, by Johan Rockström \& Owen Gaffney. (2021). Dorling Kindersley. Available as hardcover, Kindle, and audiobook; 240 pages. Publisher's website:

https://www.penguinrandomhouse.com/books/659581/brea king-boundaries-by-johan-rockstrom-and-owen-gaffney/

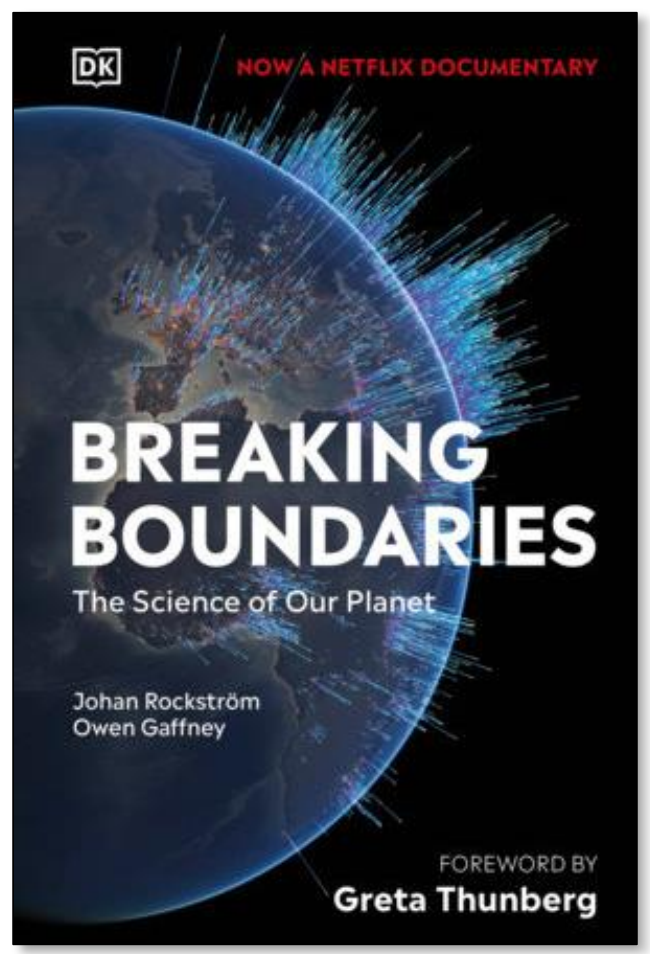

Submitted July 20, 2021 / Revised October 4, 2021 / Published online November 4, 2021

Citation: Borsari, B. (2021). Food production and Earth's limits to growth in the Anthropocene [Book review]. Journal of Agriculture, Food Systems, and Community Development, 11(1), 211-213.

https://doi.org/10.5304/jafscd.2021.111.007

Copyright (C) 2021 by the Author. Published by the Lyson Center for Civic Agriculture and Food Systems. Open access under CC-BY license.

\begin{abstract}
A griculture is the human activity that is acting $\mathrm{A}_{\text {as a major planetary force in the Anthropo- }}$ cene. Although the authors of Breaking Boundaries: The Science of Our Planet dedicated only one chapter

\footnotetext{
* Bruno Borsari, Ph.D., Department of Biology, Winona State University; Winona, MN 55987 USA; bborsari@winona.edu

Bruno Borsari is a professor emeritus in the Department of Biology at Winona State University. An agroecologist by trade, he has spent 30 years teaching, researching, and consulting in sustainable development and food systems, focusing on extension education. He was a Fulbright Scholar in Panama twice (2014-15 and 2019-20) and collaborated with universities to introduce students of agriculture and small-scale farmers to agroecology through hands-on workshops and field demonstration programs.
}

to food production (Chapter 11), they contended that four of the nine planetary boundaries within which humanity operates have been overcome by agriculture. The book is organized into three acts or sections. Act I contains four chapters describing keystone events that shaped our planet. It describes a lifeless origin dominated by geophysical processes to the onset of life and the changes brought about by photosynthesis, which spurred aerobic life and multicellular organisms. Earth is a complex system undergoing continuous changes, yet it evolved selfregulating mechanisms to regain homeostasis from disturbances (Chapter 1).

A brief history of climate change with an emphasis on the mystery of ice ages during the 
mid-19th century is reported in Chapter 2, where readers learn how carbon and its concentration shifts shaped the climate through geologic eras, despite the skepticism of the scientific community at that time, until 1941. In that year, Serbian scientist Milutin Milankovitch published Canon of Insolation of the Earth and its Applications to the Problem of the Ice Ages, which convinced the scientific community that the link between ice ages and warm interludes, or interglacials, have to do with the tilt and wobble of Earth's orbit around the sun. The swings of global temperatures during glacial periods fostered brain evolution in our hominin ancestors and selected for social and cooperative behaviors (Chapter 3). In Chapter 4, readers learn about the Holocene epoch, which for 12,000 years maintained a relatively stable climate. These conditions spurred the agricultural revolution and the rise of civilizations. The authors conclude this chapter by emphasizing that since 1950, humanity has entered the accelerating phase of the Anthropocene (a new geologic event, where human activities act as geologic forces that threaten the selfregulating mechanisms of our planet) (Kunnas, 2021). Act II presents the science of this acceleration as cause for replacing the stability of the Holocene with the uncertainties of the Anthropocene, thus justifying the call for declaring a planetary emergency.

In Chapter 5, the case is made to demonstrate the reality of the Anthropocene, and emphasis is placed on describing exponential growth, a hardto-grasp concept (e.g., the lily growing in the pond). Then, the authors introduce the boundaries as keystone constructs that humanity should consider to avoid Earth going past four critical tipping points (social, political, economic, and technological) (Chapter 6). Otherwise, a domino effect could generate a cascade of uncontrollable events, from sea-level rise due to melting glaciers and increasing atmospheric carbon leading to droughts, floods, forest fires, crop losses, and displacements of people. This urgency demands a global action plan to constrain human activities within the planetary boundaries (Chapter 8).

Act III is where the authors present various strategies to establish a renovated relationship with Earth. This narrative begins in Chapter 9, by legiti- mizing the need to improve stewardship by 2030 . "The Energy Transition" is the title of Chapter 10 to highlight a priority issue that led to the COP21 agreement of 2015, to reach zero emissions by 2050. Agriculture is heavily implicated in this issue, because $40 \%$ of gas emissions derive from this sector of the global economy. Agriculture continues to operate beyond the land and water uses and nutrient (nitrogen and phosphorous) boundaries, thus acting as the leading force that has almost converted Earth into a behemoth farm. In 2050 the human population is estimated to reach 10 billion and the authors (like many agricultural scientists) support an intensification of farming to fulfill the food needs of a growing population (Chapter 11). They suggest precision farming approaches like water use efficiency, biotechnology, smart agriculture, and selecting livestock species to make agricultural enterprises sustainable.

However, without any further explanation, these approaches aimed at solving the challenges of agriculture appear inadequate and unattainable. The authors did not consider the relevance that agroecology and agroforestry have among peasant farming communities around the world in supporting local food production while conserving the biodiversity that industrial agriculture continues to extirpate from the landscape through monocultures and confined animal feedings operations (CAFOs). For these reasons, the planetary diet that was proposed by the EAT-Lancet Commission as a way to improve both human and global health, although justifiable and necessary, may not yield its full benefits if agriculture remains industrialized and subservient to highly centralized food systems. People have been producing food for 10,000 years, and they should maintain the opportunity to do so instead of being removed from the land as a few megacorporations seize the exclusive right to farming. Agroecology is sensitive to the social and political issues of agriculture. Its benefits have become transformative and synergistic to sustainable development, where this movement has grown (Borsari, 2011).

The chapters that follow tackle inequalities (Chapter 12), urban development (Chapter 13), human population growth (Chapter 14), and technology, from artificial intelligence to geo- 
engineering (Chapter 15), the economy (Chapter 16), and policy-making (Chapter 17). The imperative remains steering human activities through the science-based framework of the planetary boundaries by the end of this decade to avoid Earth reaching the four critical tipping points (Chapter 18). The authors conclude by reiterating that humanity is still far from achieving sustainability. However, science shows that we can restabilize Earth within the next 30 years if we remain committed in the 2020s to returning to operating within planetary boundaries. This is the trajectory to fol- low if we wish to leave our children and grandchildren the stable, resilient planet they deserve to inherit (Chapter 19). The book is enhanced by color plates that illustrate concepts and data from the chapters. Forewords by environmentalist Greta Thunberg and United Nations Secretary-General António Guterres reiterate the urgency for action to resolve our complex planetary crisis. The book is not free of limitations, yet it is relevant and persuasive. It is an inspiration for restorative actions and a celebration of what has been achieved already. It is a must-read!

\section{References}

Borsari, B. (2011). Agroecology to the rescue of food security and germplasm conservation in a global market economy. International Journal of Agricultural Resources, Governance and Ecology, 9(1-2), 1-14. https://doi.org/10.1504/ijarge.2011.040215

Kunnas, J. (2021). Anthropocene event idea is empowering. Nature, 598(7880), 257. https://doi.org/10.1038/d41586-021-02753-7 